\title{
Article \\ Efficacy of Artificial Tears Based on an Extract of Artemia salina Containing Dinucleotides in a Rabbit Dry Eye Model
}

\author{
Carlos Carpena-Torres ${ }^{1}{ }^{\circledR}$, Jesus Pintor ${ }^{2}$, Fernando Huete-Toral ${ }^{2}$, Alba Martin-Gil ${ }^{1}{ }^{\mathbb{D}}$, Candela Rodríguez-Pomar ${ }^{1}$, \\ Alejandro Martínez-Águila ${ }^{2}$ and Gonzalo Carracedo ${ }^{1, *(1)}$ \\ 1 Ocupharm Research Group, Department of Optometry and Vision, Faculty of Optics and Optometry, \\ Complutense University of Madrid, C/Arcos de Jalón 118, 28037 Madrid, Spain; ccarpena@ucm.es (C.C.-T.); \\ amarting@ucm.es (A.M.-G.); candelarodriguezpomar@gmail.com (C.R.-P.) \\ 2 Ocupharm Research Group, Department of Biochemistry and Molecular Biology, Faculty of Optics and \\ Optometry, Complutense University of Madrid, C/Arcos de Jalón 118, 28037 Madrid, Spain; \\ jpintor@ucm.es (J.P.); fhueteto@ucm.es (F.H.-T.); alejandromaguila@gmail.com (A.M.-Á.) \\ * Correspondence: jgcarrac@ucm.es
}

\section{check for} updates

Citation: Carpena-Torres, C.; Pintor, J.; Huete-Toral, F.; Martin-Gil, A.; Rodríguez-Pomar, C.; MartínezÁguila, A.; Carracedo, G. Efficacy of Artificial Tears Based on an Extract of Artemia salina Containing Dinucleotides in a Rabbit Dry Eye Model. Int. J. Mol. Sci. 2021, 22, 11999. https://doi.org/10.3390/ ijms222111999

Academic Editor: Simon Kaja

Received: 3 October 2021

Accepted: 3 November 2021

Published: 5 November 2021

Publisher's Note: MDPI stays neutral with regard to jurisdictional claims in published maps and institutional affiliations.

Copyright: (c) 2021 by the authors. Licensee MDPI, Basel, Switzerland. This article is an open access article distributed under the terms and conditions of the Creative Commons Attribution (CC BY) license (https:// creativecommons.org/licenses/by/ $4.0 /)$.

\begin{abstract}
Background: Artemia salina is a brine shrimp containing high concentrations of dinucleotides, molecules with properties for dry eye treatment. For this reason, the purpose of the study was to evaluate the effect of the artificial tears based on an extract of Artemia salina in a rabbit dry eye model. (2) Methods: A prospective and randomized study was carried out. Twenty rabbits were divided into 4 groups ( $n=5$, each group): healthy rabbits, dry eye rabbits, dry eye rabbits treated with hypromellose (HPMC), and dry eye rabbits treated with Artemia salina. Dry eye was induced by the topical instillation of $0.2 \%$ benzalkonium chloride. The measurements were performed before and after the treatment for 5 consecutive days. (3) Results: The topical instillation of artificial tears containing Artemia salina showed beneficial effects on tear secretion, tear break-up time, corneal staining, the density of Goblet cells, heigh of mucin cloud secreted by these cells, and mRNA levels of IL-1 $\beta$ and MMP9 in conjunctival cells. Compared with the HPMC, there was a statistically significant improvement $(p<0.05)$ with the Artemia salina in all the variables under study, except for the conjunctival hyperemia, density of Goblet cells, and mRNA levels of IL-6. (4) Conclusions: The potential of artificial tears based on Artemia salina as a secretagogue agent for dry eye treatment was confirmed, opening the door for future clinical trials and studies to extrapolate the findings for dry eye patients.
\end{abstract}

Keywords: dry eye; Artemia salina; dinucleotides; secretagogue; purinergic signaling

\section{Introduction}

Dry eye was defined by the Tear Film and Ocular Surface Society (TFOS) as "a multifactorial disease of the ocular surface characterized by a loss of homeostasis of the tear film, and accompanied by ocular symptoms, in which tear film instability and hyperosmolarity, ocular surface inflammation and damage and neurosensory abnormalities play etiological roles" [1]. This condition affects a large portion of the world's population, reaching a prevalence of $50 \%$ in some regions of the planet [2]. For the treatment of dry eye, a remarkable family of compounds depicting interesting physiological properties on the ocular surface is dinucleoside polyphosphates, also known as dinucleotides [3].

Dinucleoside polyphosphates are formed by two nucleotides linked by a variable number of phosphates (from 2 to 7) and play an important role in the diagnosis and treatment of dry eye [4]. These compounds activate cell surface purinergic P2 receptors, both P2X ionotropic [5] and P2Y metabotropic [6] receptors. P2 receptors have been found in different parts of the eye such as the ocular surface, anterior and posterior chambers, and retina [7]. The activation of $\mathrm{P}_{2} \mathrm{Y}_{2}$ receptor, a subtype of $\mathrm{P} 2 \mathrm{Y}$ receptors, produces chloride efflux and water movement into the extracellular medium $[4,8,9]$. 
On the ocular surface, ${\mathrm{P} 2 \mathrm{Y}_{2}}_{2}$ receptor has been described in the cornea, conjunctiva, and lacrimal gland [10]. The activation of $\mathrm{P}_{2} \mathrm{Y}_{2}$ receptor via topical instillation of diadenosine tetraphosphate $\left(\mathrm{Ap}_{4} \mathrm{~A}\right)$ and diuridine tetraphosphate $\left(\mathrm{Up}_{4} \mathrm{U}\right)$ demonstrated its capability to stimulate aqueous [11-14], mucinous [15], and lipidic [16] components of tears, as well as to accelerate corneal re-epithelization $[15,17,18]$. Additionally, the instillation of these compounds increases the corneal permeability $[19,20]$ and the levels of both lysozyme [21] and lactoferrin [22] in tears.

From a clinical viewpoint, the scientific evidence supports the safety and security of the commercial form of $\mathrm{Up}_{4} \mathrm{U}$ (Diquafosol ${ }^{\circledR}$ ) as a secretagogue agent for the treatment of dry eye $[23,24]$. The Diquafosol ${ }^{\circledR}$, which is only commercially available in Asia, demonstrated its efficacy to improve the signs and symptoms of dry eye in patients with Sjögren syndrome [25], aqueous deficient dry eye [26], evaporative dry eye [27], dry eye associated with cataract surgery [23], contact lens wearers [28], and even in healthy subjects [29].

Recently, our research group developed artificial tears based on an extract of $4 \%$ Artemia salina [30], a brine shrimp containing high concentrations of dinucleotides, mainly diguanosine tetraphosphate $\left(\mathrm{Gp}_{4} \mathrm{G}\right)$, but also others such as diguanosine triphosphate $\left(\mathrm{Gp}_{3} \mathrm{G}\right)$ and diphosphate $\left(\mathrm{Gp}_{2} \mathrm{G}\right)$, or guanosine-adenosine tetraphosphate $\left(\mathrm{Gp}_{4} \mathrm{~A}\right)[31,32]$. The concentration of $4 \%$ Artemia salina was chosen in a previous study where the effect of short-term instillation of different concentrations of the brine shrimp $(2 \%, 4 \%, 6 \%, 8 \%$, and $10 \%)$ was evaluated in healthy rabbits [30]. The $4 \%$ Artemia salina manifested the best results in increasing tear secretion and improving corneal epithelial damage, also confirming its safety over the ocular surface.

The purpose of the current study was to evaluate the effect of the artificial tears based on an extract of $4 \%$ Artemia salina on lacrimal function and ocular surface damage and inflammation in a rabbit dry eye model. The dry eye model was induced by topical instillation of $0.2 \%$ benzalkonium chloride (BAC) for 5 consecutive days, a method previously validated [33], while the treatment with the artificial tears was applied simultaneously.

\section{Results}

Table 1 summarizes the values of all the variables under study before (PRE) and after (POST) the instillation of the different treatments for 5 consecutive days and the statistical comparison between PRE and POST measurements.

Table 1. Values of all the variables under study before (PRE) and after (POST) the instillation of the different treatments for 5 consecutive days. The statistical comparison was performed between the values PRE and POST in each group.

\begin{tabular}{|c|c|c|c|c|}
\hline \multirow{2}{*}{ Variable } & \multirow{2}{*}{$\begin{array}{c}\text { Group } \\
(n=5, \text { Each One })\end{array}$} & \multicolumn{2}{|c|}{ Mean \pm SD } & \multirow{2}{*}{$p$-Value } \\
\hline & & PRE & POST & \\
\hline \multirow{4}{*}{ Tear secretion $(\mu \mathrm{L})$} & Healthy & $7.0 \pm 3.4$ & $6.0 \pm 3.1$ & 0.373 \\
\hline & Dry eye & $7.8 \pm 2.2$ & $6.3 \pm 2.3$ & 0.081 \\
\hline & Dry eye + HPMC & $8.1 \pm 2.5$ & $7.4 \pm 3.0$ & 0.477 \\
\hline & Dry eye + Artemia & $7.3 \pm 2.7$ & $12.0 \pm 3.4$ & $0.008^{\wedge}$ \\
\hline \multirow{4}{*}{ Tear break-up time (s) } & Healthy & $4.2 \pm 0.7$ & $4.1 \pm 1.3$ & 0.896 \\
\hline & Dry eye & $5.4 \pm 2.7$ & $1.7 \pm 0.6$ & 0.005 * \\
\hline & Dry eye + HPMC & $5.2 \pm 1.5$ & $1.7 \pm 0.9$ & $0.005^{\wedge}$ \\
\hline & Dry eye + Artemia & $4.1 \pm 1.1$ & $2.5 \pm 1.0$ & $<0.001$ * \\
\hline \multirow{4}{*}{ Corneal staining (score) } & Healthy & $1.90 \pm 0.88$ & $1.70 \pm 1.06$ & 0.516 \\
\hline & Dry eye & $1.60 \pm 0.84$ & $4.00 \pm 0.00$ & 0.004 * \\
\hline & Dry eye + HPMC & $1.70 \pm 0.95$ & $3.70 \pm 0.48$ & 0.007 * \\
\hline & Dry eye + Artemia & $2.30 \pm 0.67$ & $3.00 \pm 0.94$ & 0.140 \\
\hline
\end{tabular}


Table 1. Cont.

\begin{tabular}{|c|c|c|c|c|}
\hline \multirow{2}{*}{ Variable } & \multirow{2}{*}{$\begin{array}{c}\text { Group } \\
(n=5, \text { Each One })\end{array}$} & \multicolumn{2}{|c|}{ Mean \pm SD } & \multirow{2}{*}{$p$-Value } \\
\hline & & PRE & POST & \\
\hline \multirow{4}{*}{ Conjunctival hyperemia (score) } & Healthy & $0.00 \pm 0.00$ & $0.10 \pm 0.32$ & 0.317 \\
\hline & Dry eye & $0.00 \pm 0.00$ & $3.40 \pm 0.70$ & $0.004 *$ \\
\hline & Dry eye + HPMC & $0.00 \pm 0.00$ & $3.50 \pm 0.85$ & $0.004^{*}$ \\
\hline & Dry eye + Artemia & $0.00 \pm 0.00$ & $2.90 \pm 0.57$ & 0.004 * \\
\hline \multirow{4}{*}{$\begin{array}{l}\text { Density of Goblet cells } \\
\quad\left(\text { cells } / \mathrm{mm}^{2}\right)\end{array}$} & Healthy & $641.2 \pm 216.7$ & $646.5 \pm 263.5$ & 0.960 \\
\hline & Dry eye & $911.7 \pm 319.9$ & $291.5 \pm 103.2$ & $<0.001 *$ \\
\hline & Dry eye + HPMC & $850.8 \pm 297.1$ & $382.9 \pm 336.2$ & $0.022 *$ \\
\hline & Dry eye + Artemia & $851.8 \pm 248.4$ & $578.4 \pm 254.1$ & 0.071 \\
\hline \multirow{4}{*}{ Height of mucin cloud $(\mu \mathrm{m})$} & Healthy & $18.4 \pm 1.0$ & $18.1 \pm 1.6$ & 0.532 \\
\hline & Dry eye & $16.8 \pm 2.1$ & $10.8 \pm 1.7$ & $<0.001$ * \\
\hline & Dry eye + HPMC & $16.7 \pm 1.2$ & $14.0 \pm 4.0$ & 0.053 \\
\hline & Dry eye + Artemia & $16.6 \pm 1.9$ & $15.5 \pm 1.9$ & 0.139 \\
\hline \multirow{4}{*}{$\begin{array}{l}\text { mRNA levels of IL-1 } \beta \\
\text { (fold change) }\end{array}$} & Healthy & $6.430 \pm 8.572$ & $3.466 \pm 3.067$ & 0.878 \\
\hline & Dry eye & $7.758 \pm 11.702$ & $42.369 \pm 42.889$ & $0.009^{\wedge}$ \\
\hline & Dry eye + HPMC & $4.103 \pm 2.772$ & $46.116 \pm 26.483$ & $0.001 *$ \\
\hline & Dry eye + Artemia & $1.295 \pm 1.838$ & $12.408 \pm 10.426$ & $0.012^{\wedge}$ \\
\hline \multirow{4}{*}{$\begin{array}{l}\text { mRNA levels of IL-6 } \\
\text { (fold change) }\end{array}$} & Healthy & $0.072 \pm 0.082$ & $0.416 \pm 0.457$ & $0.028^{\wedge}$ \\
\hline & Dry eye & $0.046 \pm 0.036$ & $0.338 \pm 0.401$ & $0.017^{\wedge}$ \\
\hline & Dry eye + HPMC & $0.051 \pm 0.086$ & $0.230 \pm 0.195$ & $0.009^{\wedge}$ \\
\hline & Dry eye + Artemia & $0.026 \pm 0.033$ & $0.175 \pm 0.132$ & $0.025^{\wedge}$ \\
\hline \multirow{4}{*}{$\begin{array}{l}\text { mRNA levels of MMP9 } \\
\text { (fold change) }\end{array}$} & Healthy & $0.028 \pm 0.034$ & - & - \\
\hline & Dry eye & $0.042 \pm 0.059$ & $0.314 \pm 0.266$ & $0.009^{\wedge}$ \\
\hline & Dry eye + HPMC & $0.030 \pm 0.017$ & $0.525 \pm 0.483$ & $0.005^{\wedge}$ \\
\hline & Dry eye + Artemia & $0.012 \pm 0.017$ & $0.174 \pm 0.176$ & $0.012^{\wedge}$ \\
\hline
\end{tabular}

${ }^{*} p<0.05$, Student's $t$-test for paired samples (normal distributions); ${ }^{\wedge}<0.05$, Wilcoxon signed-rank test (non-normal distributions); Artemia: Artemia salina; HPMC: hypromellose.

\subsection{Tear Secretion and Tear Break-Up Time}

Figure 1 shows the normalized effect after the instillation of the different treatments on both tear secretion and tear break-up time, and the statistical comparison between all the groups.

Concerning tear secretion, the group of rabbits with dry eye treated with Artemia salina was the only one that showed a statistically significant increase of $64.38 \pm 18.41 \%$ in comparison with the rest of the groups $(p<0.05)$. The other groups did not show statistical differences between them nor changes in comparison with their baseline measurements $(p \geq 0.05)$.

In relation to tear break-up time, there was a statistically significant deterioration in the three groups of rabbits with induced dry eye in comparison with the healthy rabbits $(p<0.05)$. This deterioration was $69.13 \pm 25.31 \%$ in the dry eye group, $67.78 \pm 36.16 \%$ in the dry eye + HPMC group, and $37.73 \pm 14.85 \%$ in the dry eye + Artemia salina group. Additionally, the treatment with Artemia salina in the rabbits with induced dry eye statistically improved the tear break-up time in comparison with the instillation of HPMC $(p=0.001)$. 


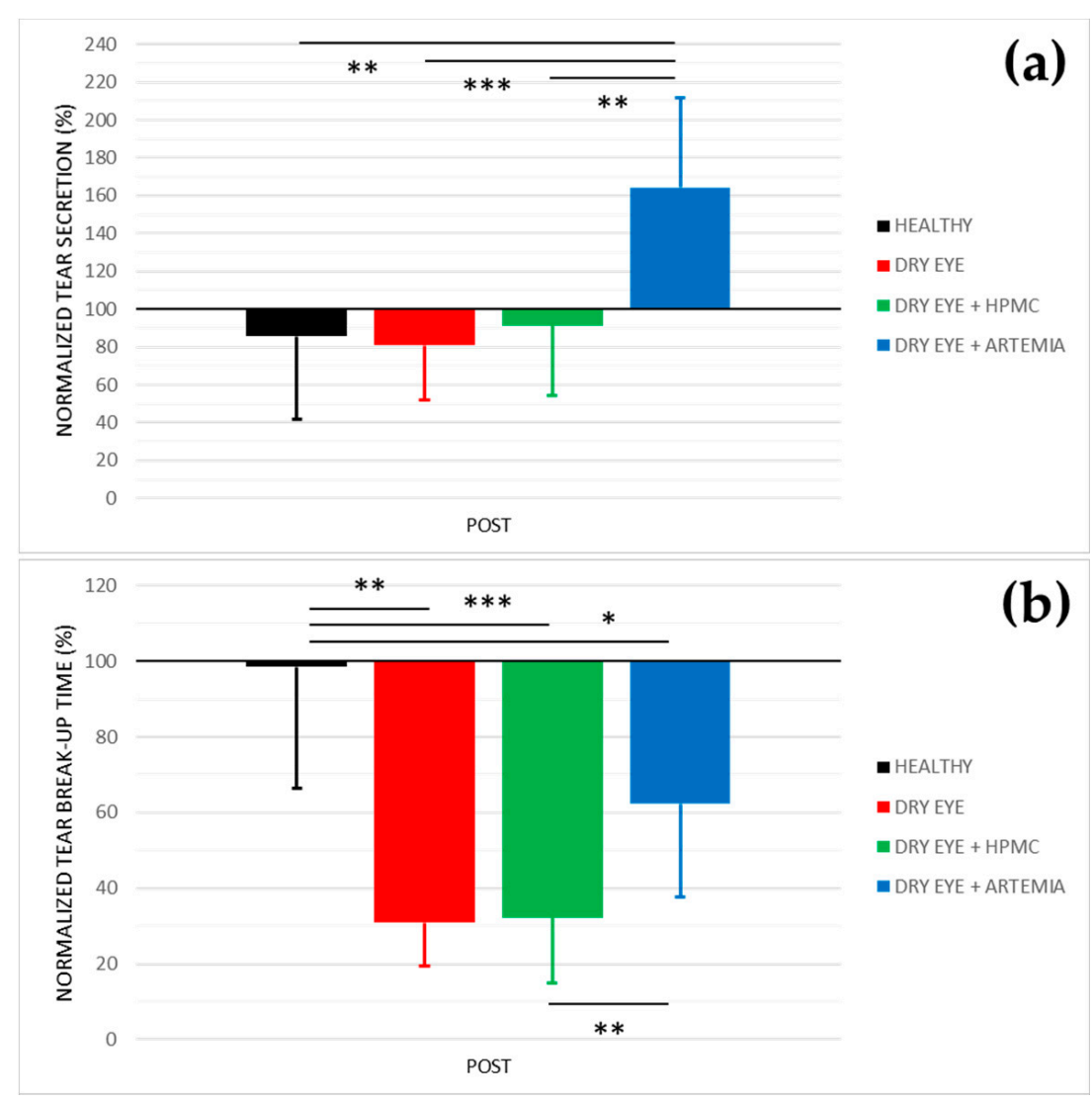

Figure 1. Normalized effect on tear secretion (a) and tear break-up time (b) of the instillation of the different treatments for 5 consecutive days. The values higher or lower than $100 \%$ represent an increase or decrease in comparison with their baseline, respectively. The statistical comparison was performed between the different groups ( $n=5$, each group). ${ }^{*} p<0.05,{ }^{* *} p<0.01,{ }^{* * *} p<0.001$, Student's $t$-test for independent samples.

\subsection{Slit-Lamp Examination}

Figure 2 shows the effect after the instillation of the different treatments on both corneal staining and conjunctival hyperemia, and the statistical comparison between all the groups. The effect on both variables was not normalized in percentage because they are discrete variables.

Regarding corneal staining, both healthy rabbits and the rabbits with induced dry eye treated with Artemia salina showed a statistically significant improvement in comparison with the rabbits with dry eye not treated and treated with HPMC $(p<0.05)$. On the other hand, despite the rabbits with dry eye being treated with Artemia salina, presenting a deterioration in comparison with their baseline, there were no statistical differences with the healthy rabbits $(p=0.109)$.

In terms of conjunctival hyperemia, there was a statistically significant deterioration in the three groups of rabbits with induced dry eye in comparison with the healthy rabbits $(p<0.05)$. Furthermore, the treatments with Artemia salina and HPMC had no effect since they showed no statistical differences with the rabbits with dry eye used as positive controls $(p \geq 0.05)$. 


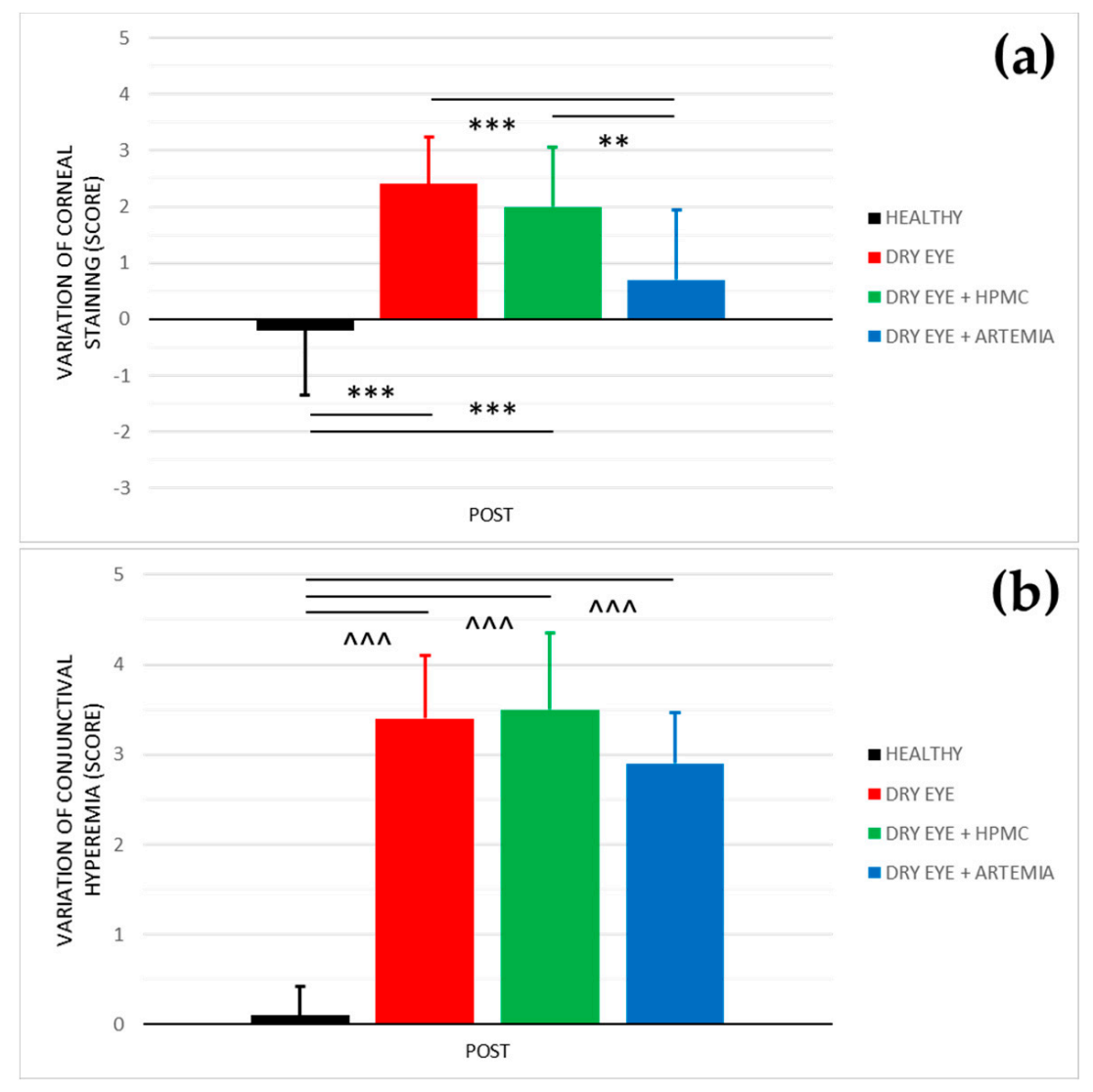

Figure 2. Variation of corneal staining (a) and conjunctival hyperemia (b) after the instillation of the different treatments for 5 consecutive days. The values higher or lower than 0 represent a deterioration or an improvement in comparison with their baseline, respectively. The statistical comparison was performed between the different groups ( $n=5$, each group). ${ }^{* *} p<0.01,{ }^{* * *} p<0.001$, Student's $t$-test for independent samples (normal distributions). ${ }^{\wedge} p<0.001$, Mann-Whitney U test (non-normal distributions).

\subsection{Conjunctival Cytology}

Figure 3 shows the normalized effect after the instillation of the different treatments on both density of Goblet cells and height of mucin cloud, and the statistical comparison between all the groups, while Figure 4 shows representative images used to quantify the density of Goblet cells in the different groups.

Concerning the density of Goblet cells, the two groups of rabbits with induced dry eye treated or not treated with HPMC suffered a statistically significant deterioration of $68.03 \pm 24.10 \%$ and $55.00 \pm 48.29 \%$, respectively, in comparison with the healthy rabbits $(p<0.05)$. Conversely, despite the rabbits with dry eye being treated with Artemia salina they also showed a deterioration compared with the healthy rabbits, these differences, however, were not statistically significant $(p=0.117)$.

Regarding the height of mucin cloud, again the two groups of rabbits with induced dry eye treated or not treated with HPMC suffered a deterioration of $35.81 \pm 5.78 \%$ and $16.31 \pm 4.70 \%$, respectively, which was statistically significant in comparison with the healthy rabbits and the rabbits with dry eye treated with Artemia salina $(p<0.05)$. In addition, the treatment with Artemia salina in the rabbits with dry eye showed similar results to the healthy rabbits $(p=0.329)$. 

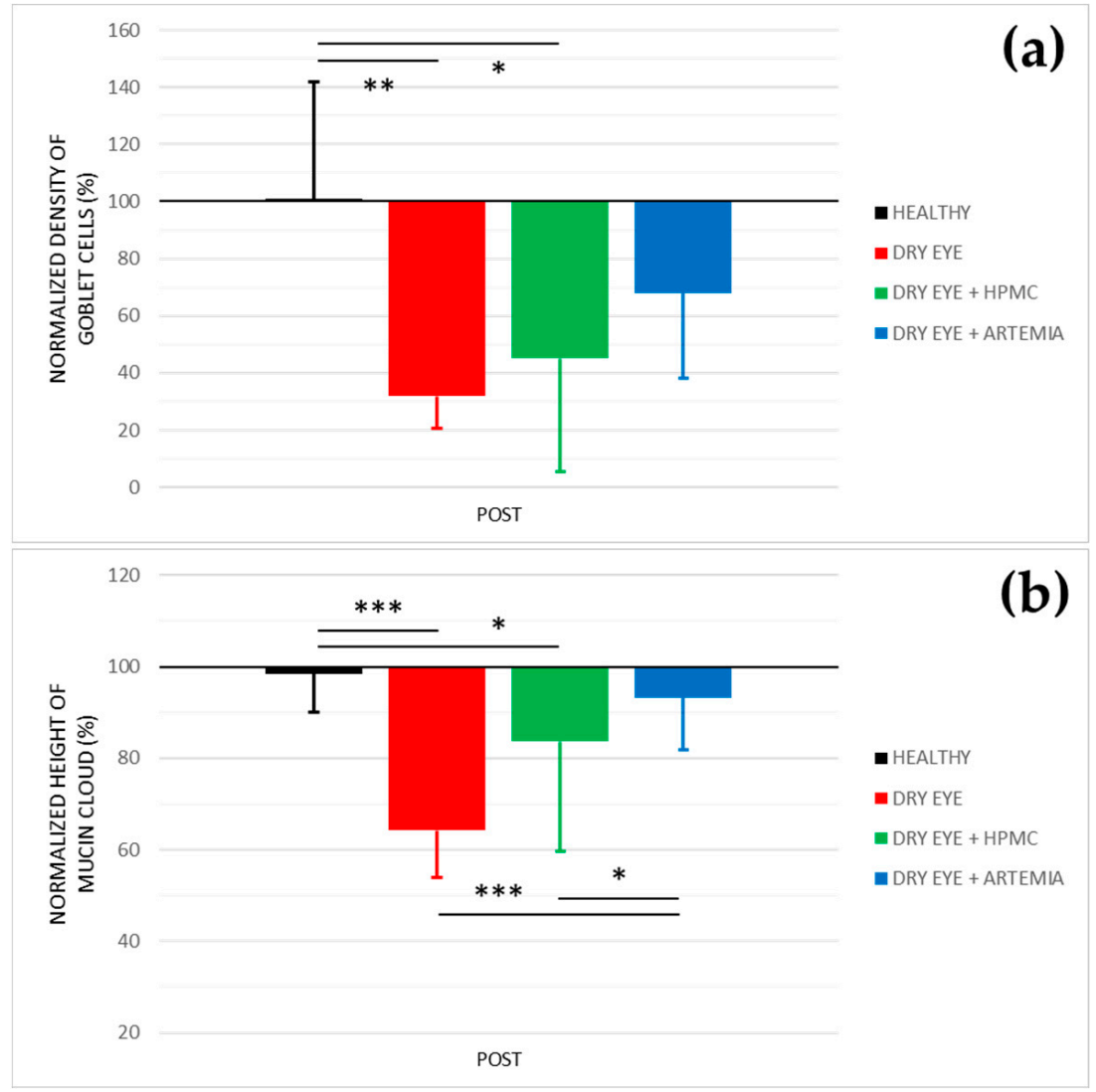

Figure 3. Normalized effect on the density of Goblet cells (a) and height of mucin cloud (b) of the instillation of the different treatments for 5 consecutive days. The values higher or lower than $100 \%$ represent an increase or decrease in comparison with their baseline, respectively. The statistical comparison was performed between the different groups ( $n=5$, each group). ${ }^{*} p<0.05,{ }^{* *} p<0.01$, *** $p<0.001$, Student's $t$-test for independent samples.

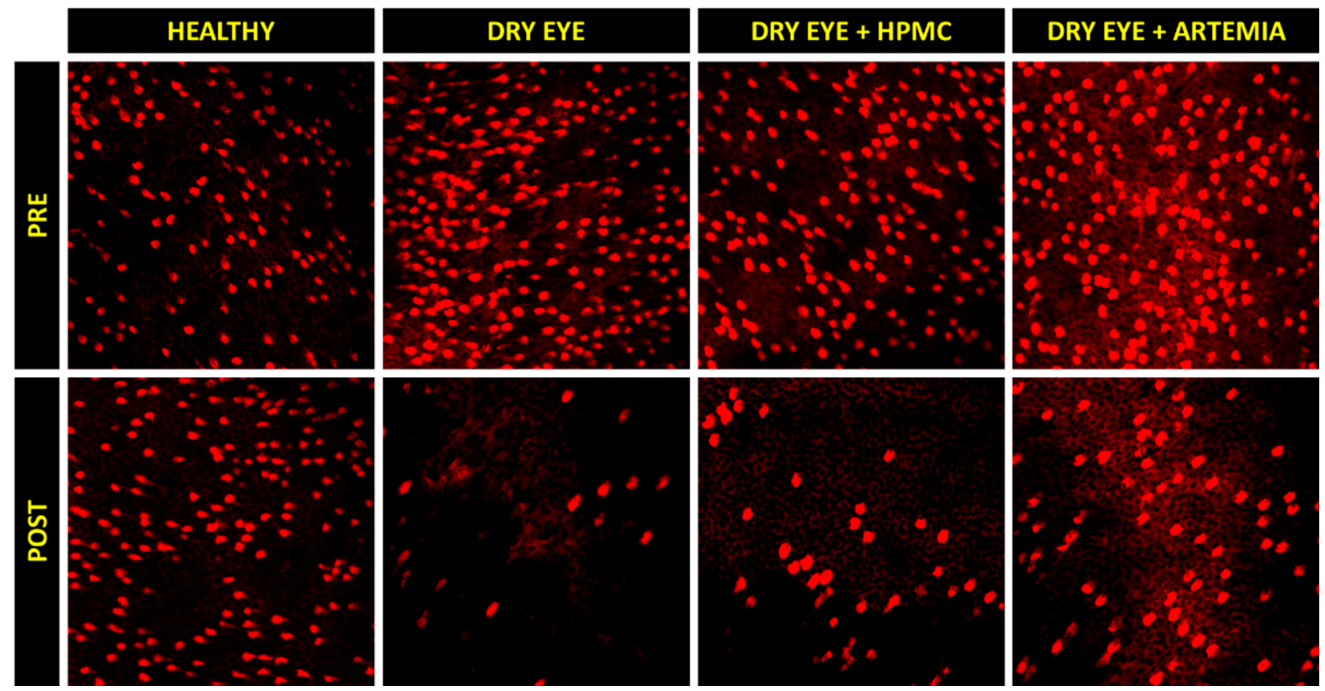

Figure 4. Representative images of the density of Goblet cells before (PRE) and after (POST) the instillation of the different treatments for 5 consecutive days. A decrease can be observed in the density of Goblet cells (brightest cells) in the three groups of rabbits with induced dry eye, but this decrease occurred in a lesser magnitude with the artificial tears based on Artemia salina. 


\subsection{Quantitative PCR}

Figure 5 shows the effect after the instillation of the different treatments on the mRNA levels of IL-1 $\beta$, IL-6, and MMP9, and the statistical comparison between all the groups. Previously, these results were normalized with the signal of the HPRT1 gene (Table 1), the reason why they were not normalized again in percentage.

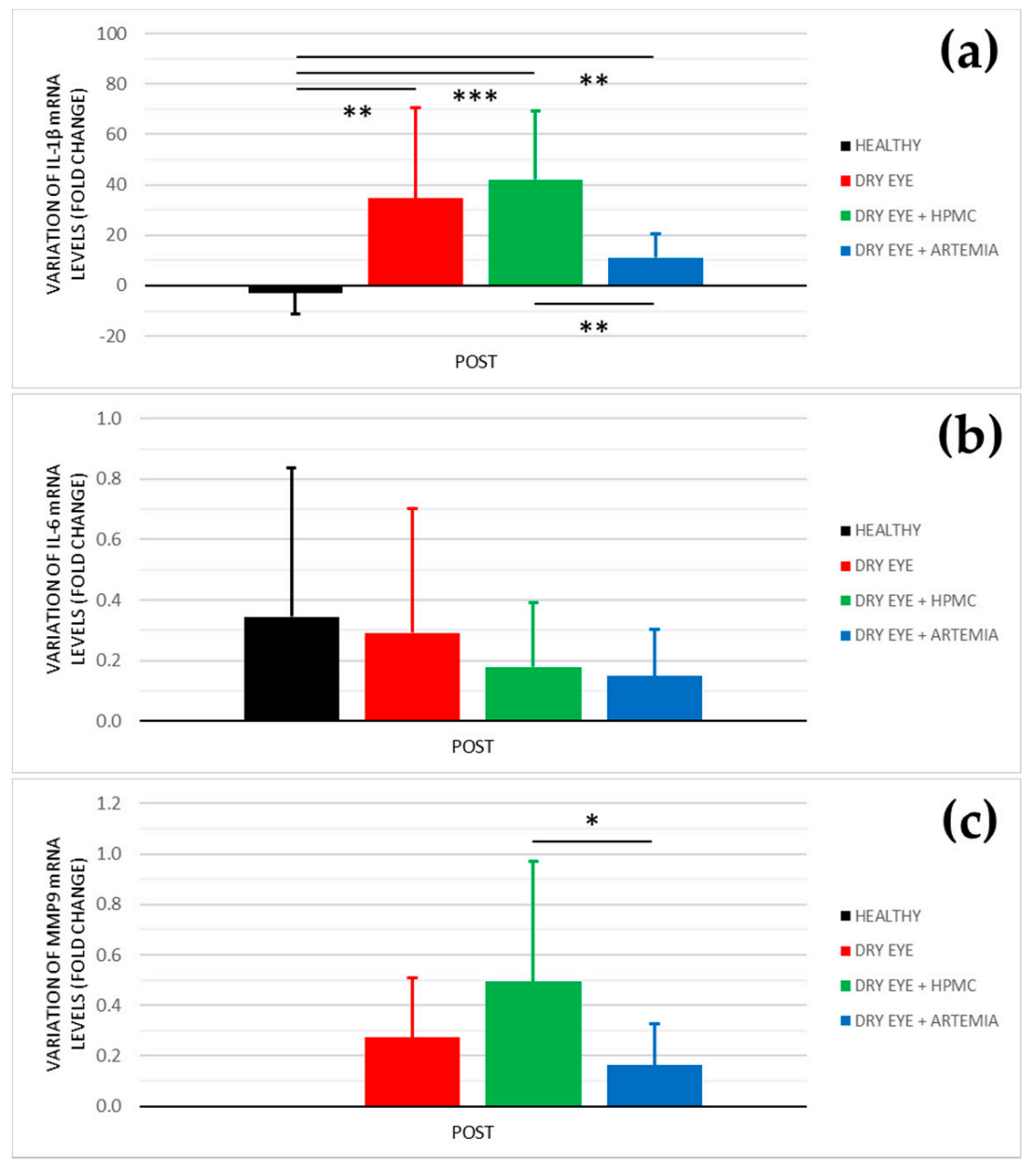

Figure 5. Variation of mRNA levels of IL-1 $\beta$ (a), IL-6 (b), and MMP9 (c) after the instillation of the different treatments for 5 consecutive days. The values higher or lower than 0 represent a deterioration or an improvement in comparison with their baseline, respectively. The statistical comparison was performed between the different groups ( $n=5$, each group). ${ }^{*} p<0.05,{ }^{* *} p<0.01$, *** $p<0.001$, Mann-Whitney U test.

In the levels of IL-1 $\beta$, the three groups of rabbits with induced dry eye showed a fold increase of $34.611 \pm 35.999$ in the dry eye group, $42.014 \pm 27.068$ in the dry eye + HPMC group, and $11.114 \pm 9.537$ in the dry eye + Artemia salina group that was statistically significant in comparison with the healthy rabbits $(p<0.05)$. Additionally, the treatment with Artemia salina produced a decrease in the mRNA expression of IL-1 $\beta$ in comparison with the HPMC $(p=0.001)$.

Regarding the levels of IL-6, there were no statistically significant differences between all the groups $(p \geq 0.05)$, despite the rabbits with dry eye treated with Artemia salina and HPMC showed lower values.

In relation to the levels of MMP9, the quantitative PCR did not detect signals for the POST measurements of the healthy rabbits. However, in the rabbit with induced dry eye, the treatment with Artemia salina decreased the mRNA expression of MMP9 in comparison 
with the HPMC $(p=0.021)$. The fold change was $0.162 \pm 0.165$ with the Artemia salina and $0.494 \pm 0.477$ with the HPMC.

\section{Discussion}

The current study reported on the effect of artificial tears based on an extract of $4 \%$ Artemia salina in a rabbit dry eye model. The treatment with these artificial tears manifested beneficial effects on tear secretion, tear break-up time, corneal staining, the density of Goblet cells, height of mucin cloud, and inflammatory biomarkers. Additionally, the safety of these artificial tears was already confirmed in a previous study performed in healthy rabbits by our research group [30].

In terms of tear secretion, the topical instillation of artificial tears with $4 \%$ Artemia salina produced an increase of $64 \%$ in the rabbits with induced dry eye (see Figure 1), values slightly higher than those previously reported by our research group after the instillation of the same extract in health rabbits (44\%) [30], but both studies showed an increase of around $4-5 \mu \mathrm{L}$ compared with their baseline. The secretagogue effect on the aqueous component of tears was associated with the agonist action of dinucleoside polyphosphates present in Artemia salina, especially $\mathrm{Gp}_{4} \mathrm{G}$, on $\mathrm{P}_{2} \mathrm{Y}_{2}$ receptors expressed in the conjunctival epithelium [11-14]. Nevertheless, it is still unknown whether $\mathrm{Gp}_{4} \mathrm{G}$ or other nucleotides present in the crustacean specifically activate the $\mathrm{P}_{2} \mathrm{Y}_{2}$ receptor as other dinucleotides such as $A p_{4} \mathrm{~A}$ and $U \mathrm{p}_{4} \mathrm{U}$. In this regard, different studies found that the topical instillation of $\mathrm{Ap}_{4} \mathrm{~A}$ increased tear secretion by around $40-50 \%$ in healthy New Zealand white rabbits through the activation of the $\mathrm{P}_{2} \mathrm{Y}_{2}$ receptor $[11,13]$. The topical instillation of $\mathrm{Up}_{4} \mathrm{U}$ or Diquafosol@also demonstrated its capability to stimulate tear secretion by $33 \%$ in the same rabbits [12,14].

On the other hand, it should be noted that the instillation of $0.2 \%$ BAC to induce the dry eye did not decrease tear secretion in comparison with the group of healthy rabbits (see Figure 1), contrary to what happened in previous experiments [33]. This fact would question the use of this animal model to study the aqueous deficient dry eye.

The artificial tears containing Artemia salina also improved tear break-up time compared with the topical instillation of HPMC in the rabbits with induced dry eye (see Figure 1), which manifested the beneficial effect of the extract of Artemia salina on tear film stability. However, the comparison of POST measurements between both groups only showed an increase lower than $1 \mu \mathrm{L}$ after the treatment with Artemia salina (see Table 1), not considered relevant for improving the severity of dry eye. To our knowledge, only the previous study of our research performed in healthy rabbits evaluated tear break-up time after a treatment containing dinucleotides, where there were no changes with the extract of $4 \%$ Artemia salina [30]. On the other hand, different studies demonstrated that the activation of the $\mathrm{P}_{2} \mathrm{Y}_{2}$ receptor by topical instillation of $\mathrm{Up}_{4} \mathrm{U}$ stimulates the production of mucins and lipids in the Goblet cells and Meibomian glands, respectively [15,16,34,35]. Considering that mucins and lipids are the responsible components for tear film stability [36], the possibility that the artificial tears with Artemia salina improves this stability in future clinical studies should not be discarded based on the hypothesis that the Gp4G present in the crustacean could act as an agonist of $\mathrm{P}_{2} \mathrm{Y}_{2}$ receptor.

Concerning the analysis of conjunctival cytologies by confocal microscopy, the secretagogue effect on the mucinous component of tears after the treatment with artificial tears containing Artemia salina was confirmed (see Figure 3). In terms of density of Goblet cells, the topical instillation of Artemia salina in the rabbits with induced dry eye did not show statistical differences with any group, including the healthy rabbits. This could indicate a protective effect against cell death induced by the instillation of $0.2 \%$ BAC. The results of the height of mucin cloud also demonstrated that the amount of mucin secreted by Goblet cells was higher after the treatment with Artemia salina due to there being no differences with the healthy rabbits and the mucin cloud increased compared with the untreated rabbits with dry eye. As mentioned above, the secretagogue effect on the mucinous component of tears is associated with the agonist action of dinucleotides on the $\mathrm{P}_{2} \mathrm{Y}_{2}$ receptors expressed 
in Goblet cells, despite only having been confirmed in the case of $\mathrm{Up}_{4} \mathrm{U}[15,34]$, but no other dinucleotides such as $\mathrm{Ap}_{4} \mathrm{~A}$ or $\mathrm{Gp}_{4} \mathrm{G}$. In this context, different studies performed on rabbits and rats found that topical instillation of $\mathrm{Up}_{4} \mathrm{U}$ stimulated the production of mucins in Goblet cells [15,34] and increased the concentration of MUC5A dissolved in tears [37,38]. In humans, Shigeyasu et al. [39,40] reported an increase in the concentration of sialic acid, a molecule that binds to the ends of mucin chains, in tears after the short- and long-term instillation of $\mathrm{Up}_{4} \mathrm{U}$.

Moreover, the treatment with artificial tears based on Artemia salina helped to protect the corneal epithelium against the damage produced by the topical instillation of $0.2 \% \mathrm{BAC}$ due to corneal staining showed an improvement compared to the rabbits with induced dry eye treated and untreated with HPMC (see Figure 2). Again, the wound healing properties of the extract of Artemia salina were associated with the possible agonist action of its dinucleotides on $\mathrm{P}_{2} \mathrm{Y}_{2}$ receptors localized in the corneal epithelium as has been confirmed experimentally with $\mathrm{Ap}_{4} \mathrm{~A}$ and $\mathrm{Up}_{4} \mathrm{U}$ [15,18,41-43]. Through this cellular mechanism, our research group found that the topical instillation of Ap4A accelerated wound healing by stimulating the cell migration of corneal epithelium $[17,18]$. Also, Fujihara et al. [15] demonstrated that the instillation of $\mathrm{Up}_{4} \mathrm{U}$ reduced corneal staining in an animal dry eye model. Conversely, other dinucleotides such as diadenosine triphosphate $\left(\mathrm{Ap}_{3} \mathrm{~A}\right)$ and pentaphosphate $\left(\mathrm{Ap}_{5} \mathrm{~A}\right)$ act as agonists of the $\mathrm{P}_{2} \mathrm{Y}_{6}$ receptor, which is also expressed in corneal epithelium, decelerating corneal wound healing by inhibiting cell migration $[18,44,45]$.

Regarding the quantitative PCR of the conjunctival cytologies, the artificial tears based on Artemia salina reduced the mRNA levels of IL-1 $\beta$ and MMP9 compared with the instillation of HPMC (see Figure 5), suggesting a possibly beneficial effect on ocular surface inflammation. Nevertheless, the treatment with Artemia salina did not show statistical differences with the rabbits with induced dry eye used as positive controls. This lack of statistical significance was associated with the high variability that showed the positive controls, as is observed in the standard deviation of the results. The increase of sample size may have confirmed the trend of the extract of Artemia salina to reduce the mRNA levels of IL-1 $\beta$ and MMP9. Recent studies demonstrated the efficacy of Up4U or Diquafosol@to reduce ocular surface inflammation in both in vitro and in vivo dry eye models $[38,46-48]$. These studies found a reduction in the protein and mRNA expression of IL- $1 \beta$ and IL6 , among other biomarkers, which agrees with the results obtained with the artificial tears containing Artemia salina in the current study. Kim et al. [46] and Park et al. [48] found that this anti-inflammatory effect is mediated by the nuclear factor $\mathrm{kB}$ pathway, which also regulates the MMP9 expression [49]. However, it is unknown whether the antiinflammatory properties of dinucleotides on the ocular surface are mediated by purinergic P2Y receptors, as occurs in other systemic pathologies [50], or are a consequence of the protective effect of these compounds against ocular surface damage and loss of homeostasis.

An important aspect of using the rabbit dry eye model induced by the topical instillation of BAC is that this model is not stable over time. Li et al. [51] reported that the signs of dry eye were sustained between 2 and 3 weeks after finishing the instillation of $0.1 \%$ BAC for 14 consecutive days. Under this context, different studies applied their treatments simultaneously to the instillation of BAC [52-56] or during the period of reversibility of the dry eye model [57-61]. In the current study, this aspect was considered for the final study design since it was previously confirmed that the instillation of the Artemia salina together with the $0.2 \%$ BAC offered better results than the instillation of Artemia salina during the period of reversibility.

Finally, the main limitation of the current study was that the interaction between the dinucleotides present in the extract of Artemia salina and purinergic P2 receptors localized on the ocular surface was not characterized. Therefore, it is only possible to hypothesize about the agonist action of $\mathrm{Gp}_{4} \mathrm{G}$ on the $\mathrm{P}_{2} \mathrm{Y}_{2}$ receptor to justify the beneficial effect of the artificial tears on tear secretion, corneal staining, the density of Goblet cells, and height of mucin cloud. On the other hand, the rabbit dry eye model induced by topical instillation of 
$0.2 \%$ BAC did not reproduce the chronic character of dry eye, this being the reason why it was not possible to evaluate the long-term treatment with the artificial tears containing Artemia salina.

\section{Materials and Methods \\ 4.1. Study Design}

An experimental, prospective, and randomized study was carried out. All the trials were performed before (PRE) and after (POST) the topical instillation of the different treatments: saline solution as negative control (healthy group), $0.2 \% \mathrm{BAC}+$ saline solution (dry eye group), $0.2 \% \mathrm{BAC}+0.24 \%$ hypromellose (dry eye $+\mathrm{HPMC}$ group), and $0.2 \% \mathrm{BAC}$ + artificial tears containing Artemia salina (dry eye + Artemia salina).

The $0.2 \%$ BAC was used to induce the dry eye model by instilling $35 \mu \mathrm{L}$, twice per day (at 10:00 and 18:00), for 5 consecutive days, except on the last day when there was a single instillation during the morning [33]. For the $0.24 \%$ HPMC or artificial tears with Artemia salina, $35 \mu \mathrm{L}$ were instilled 3 times per day (at 12:00, 14:00, and 16:00), for 5 consecutive days. In total, there were 9 instillations of $0.2 \%$ BAC or saline solution per eye in each rabbit and 15 instillations of HPMC, Artemia salina, or saline solution.

On the last day, the measurements were taken $20 \mathrm{~min}$ after the last instillation at 16:00, when dinucleotides produce the maximum effect on tear secretion $[13,14]$. The order of the trials was as follows: tear secretion, slit-lamp examination (including tear break-up time), and conjunctival cytology.

\subsection{Animals}

A total of 20 male New Zealand white rabbits were used in the study, including both eyes in the same experimental group $\left(\mathrm{n}_{\text {eyes }}=40\right)$. The rabbits were randomly divided into four groups: 5 rabbits as negative control (healthy group, $\mathrm{n}_{\text {eyes }}=10$ ), 5 rabbits with induced dry eye as a positive control (dry eye group, $\left.\mathrm{n}_{\text {eyes }}=10\right), 5$ rabbits with induced dry eye and treated with HPMC (dry eye + HPMC group, $\left.\mathrm{n}_{\text {eyes }}=10\right)$, and 5 rabbits with induced dry eye and treated with artificial tears of Artemia salina (dry eye + Artemia salina, $\left.\mathrm{n}_{\text {eyes }}=10\right)$.

The rabbits were provided by the animal facility of the Faculty of Veterinary of the Complutense University of Madrid. They were kept in cages for 7 days before experimentation to get them used to their new housing conditions. Their weight was between 3.0 and $3.5 \mathrm{~kg}$ and they had free access to food and water. The rabbits were under controlled conditions: $12 \mathrm{~h}$ light-dark cycles, a temperature of $18{ }^{\circ} \mathrm{C}$, and a humidity of $30 \%$.

\subsection{Artificial Tears}

The artificial tears based on an extract of Artemia salina were manufactured and provided by the company Avizor (Avizor, Madrid, Spain). The qualitative composition of these artificial tears was as follows: an extract of $4 \%$ Artemia salina containing $10 \mu \mathrm{M}$ of $\mathrm{Gp}_{4} \mathrm{G}$ as an active ingredient, $0.24 \% \mathrm{HPMC}$ as a thickening agent, boric acid and borax as a buffer, and $\mathrm{CaCl}_{2}, \mathrm{KCl}$, and $\mathrm{MgCl}_{2}$ as electrolytes. The artificial tears had an osmolality of $248 \mathrm{mOsm} / \mathrm{kg}$, a pH of 7.1, and a viscosity of $5.6 \mathrm{cP}$.

The treatment with HPMC had the same composition as the artificial tears of Artemia salina but with no crustacean extract. The saline solution used during the experiments was also provided by Avizor, while the BAC was provided by Merck (Merck, Darmstadt, Germany).

\subsection{Tear Secretion and Tear Break-Up Time}

Tear secretion with anesthesia was measured by performing a Schirmer's test (Aiesi; Naples, Italy) for $5 \mathrm{~min}$. The paper strip was positioned in the inferior lid and the rabbit's eyes were closed to avoid the reflex secretion associated with blinking. Each millimeter of the paper strip soaked corresponded to $1 \mu \mathrm{L}$ of tear secretion. The topical anesthesia was induced by the instillation ( 2 drops in $5 \mathrm{~min}$ ) of commercial eye drops containing $4 \mathrm{mg} / \mathrm{mL}$ 
of oxybuprocaine hydrochloride and $1 \mathrm{mg} / \mathrm{mL}$ of tetracaine hydrochloride (Alcon Cusí, Barcelona, Spain). Tear secretion was measured $5 \mathrm{~min}$ after the last instillation of anesthesia.

Tear break-up time was measured during the slit-lamp examination. It was evaluated after the instillation of $2 \mu \mathrm{L}$ of commercial $2 \%$ fluorescein sodium (Alcon Cusí) over the ocular surface. Three consecutive measurements were taken with a timer after manually forcing the rabbits to blink.

\subsection{Slit-Lamp Examination}

The signs of ocular surface damage were examined with a VX75 slit lamp (Luneau Technology, Chartres, France). The severity of corneal staining and conjunctival hyperemia was quantified by using the Efron Grading Scales [62], which classify this severity as follows: normal (0), trace (1), mild (2), moderate (3), and severe (4). Corneal staining was measured immediately after measuring tear break-up time with fluorescein sodium.

\subsection{Conjunctival Cytology}

The medical device EYEPRIM (Opia Technologies, Paris, France) was used to collect the superficial conjunctival cells. Two cytologies of both superior and inferior quadrants of the bulbar conjunctiva were taken. The superior cytology was used to quantify the density of Goblet cells and the height of mucid cloud of these cells, while the inferior cytology was used to quantify the mRNA levels of interleukin $1 \beta$ (IL-1 $\beta$ ), IL-6, and metalloproteinase 9 (MMP9) by polymerase chain reaction (PCR).

The superior cytology was fixed in $96 \%$ ethanol at $4{ }^{\circ} \mathrm{C}$ for $24 \mathrm{~h}$ to be stained with the hematoxylin-periodic acid Schiff procedure posteriorly. For the visualization of the Goblet cells, a confocal microscopy system FV1200 (Olympus, Tokyo, Japan) was used, while the images were analyzed with the ImageJ software (National Institutes of Health; Bethesda, MD, USA). The samples were excited by a wavelength of $559 \mathrm{~nm}$ and the light emission was filtered for a range between 580 and $620 \mathrm{~nm}$. Magnifications of x20 and x40 were used for the quantification of the density of Goblet cells and the height of mucin cloud, respectively. The Z-stacking to visualize the three-dimensional cells was performed with a pupil diameter of $180 \mu \mathrm{m}$ and a stack interval of $0.25 \mu \mathrm{m}$. All of these procedures were previously detailed by Peral and Pintor [63].

The density of Goblet cells was quantified in 5 different regions of each sample, while the height of mucin cloud, including the cell thickness, was quantified in 15 different cells.

\subsection{Quantitative PCR}

The inferior conjunctival cytology was fixed in RNAlater (Thermo Fisher Scientific, Waltham, MA, USA) at $4{ }^{\circ} \mathrm{C}$ for $24 \mathrm{~h}$. Then, RNAlater was removed and the samples were stored at $-80^{\circ} \mathrm{C}$ until being processed.

The RNA isolation and purification of the samples were performed with the commercial kits QIAshredder and RNeasy Mini Kit (Qiagen, Hilden, Germany), following the manufacturer's instructions.

Twenty-two $\mu \mathrm{L}$ of the total RNA were used for the first-strand cDNA synthesis that was performed with the High Capability cDNA Reverse Transcription Kit and random hexamer primers (Thermo Fisher Scientific). The quantitative PCR was carried with the QuantStudio 3 system (Thermo Fisher Scientific) by using the cDNA, Quantitect SYBR Green Kit (Qiagen), and specific primers of IL-1 $\beta$, IL-6, and MMP9 (Table 2). The hypoxanthine-guanine phosphoribosyltransferase 1 (HPRT1) gene was used as an internal control to normalize the mRNA relative expression. Each sample was triplicated and negative controls were included in all the measurements. The thermal cycler program was as follows: $15 \mathrm{~min}$ at $95^{\circ} \mathrm{C}, 40$ cycles of $15 \mathrm{~s}$ at $94{ }^{\circ} \mathrm{C}, 30 \mathrm{~s}$ at $55^{\circ} \mathrm{C}$, and $34 \mathrm{~s}$ at $72{ }^{\circ} \mathrm{C}$. 
Table 2. Sequences of the different primers analyzed by quantitative polymerase chain reaction.

\begin{tabular}{|c|c|}
\hline Primer & Sequence (Forward/Reverse) \\
\hline HPRT1 & $\begin{array}{c}\text { 5'-CTGGCAAAACAATGCAGACCT-3' / } \\
\text { 5'-GTCCTTTTCACCAGCAGGCTT-3' }\end{array}$ \\
\hline IL-1 $\beta$ & $\begin{array}{l}5^{\prime} \text {-TTGAAGAAGAACCCGTCCTCTG-3' } \\
5^{\prime} \text {-CTCATACGTGCCAGACAACACC-3' }\end{array}$ \\
\hline IL-6 & $\begin{array}{c}\text { 5'-GCCTCACAAACTTCCTGGAG-3' / } \\
5^{\prime} \text {-GATGGTGTGTTCTGACCGTG-3' }\end{array}$ \\
\hline MMP9 & $\begin{array}{l}5^{\prime} \text {-AAGACGCAGACGGTGGATTC-3' / } \\
5^{\prime} \text {-ACTCACACGCCAGAAGAAGC-3' }\end{array}$ \\
\hline
\end{tabular}

HPRT1: hypoxanthine-guanine phosphoribosyltransferase 1; IL-1 $\beta$ : interleukin 1 $\beta$; IL-6: interleukin 6; MMP9: metalloproteinase 9.

The analysis of the melting curves confirmed the specificity of the primers and the absence of primer-dimers. Finally, both the stability of the HPRT1 gene and the analysis of the quantitative PCR data were performed by the $2^{-\Delta \mathrm{Ct}}$ method.

\subsection{Statistical Analysis}

The statistical analysis was performed with the SPSS 23 software (IBM; Chicago, IL, USA). The normality of all the variables was checked using the Shapiro-Wilk test. The comparison between the measurements before (PRE) and after (POST) the instillation of the different treatments was carried out with the Student's $t$-test for paired samples (normal distributions) or the Wilcoxon signed-rank test (non-normal distributions). Besides, the comparison of the effect of the different treatments (difference between PRE and POST measurements) between groups was performed using the Student's $t$-test for independent samples (normal distributions) or the Mann-Whitney U test (non-normal distributions). A statistical significance of $95 \%(p<0.05)$ was established in all the tests.

The analyzed variables were: tear secretion, tear break-up time, corneal staining, conjunctival hyperemia, density of Goblet cells, height of mucin cloud, and mRNA levels of IL-1 $\beta$, IL-6, and MMP9. Results are reported as mean \pm standard deviation (SD).

\section{Conclusions}

The artificial tears based on an extract of $4 \%$ Artemia salina showed secretagogue properties on aqueous and mucinous components of tears, accompanied by a protective effect against ocular surface damage and inflammation in a rabbit dry eye model. Thus, the potential of these artificial tears as a secretagogue agent for dry eye treatment was confirmed, which opens the door for future clinical trials and studies to extrapolate the findings to dry eye patients.

\section{Patents}

Pintor Just, J.J.; Pérez de Lara, M.J.; Huete Toral, F.; Colligris, B.; Carracedo Rodríguez, J.G. WO/2018/015582-Preparation and use of an extract of Artemia salina to treat the ocular surface. 2017.

Author Contributions: Conceptualization, G.C., F.H.-T., J.P. and C.C.-T.; methodology, G.C., F.H.-T. and C.C.-T.; investigation, C.C.-T. and A.M.-G.; resources, C.R.-P. and A.M.-Á.; writing-original draft preparation, C.C.-T.; writing—review and editing, G.C.; visualization, F.H.-T., A.M.-G., C.R.-P. and A.M.-Á.; supervision, G.C. and F.H.-T.; project administration, G.C. All authors have read and agreed to the published version of the manuscript.

Funding: This research received no external funding. 
Institutional Review Board Statement: This study was performed in compliance with the ARVO Statement for the Use of Animals in Ophthalmic and Vision Research and with the Directive 2010/63/EU of the European Parliament and of the Council on the protection of animals used for scientific purposes.

Informed Consent Statement: Not applicable.

Data Availability Statement: The data used to support the findings of this study are available from the corresponding author upon request.

Acknowledgments: This study was published in memory of Jesus Pintor, who passed away on 2 April 2019. He founded and led our research group working continuously on the relation between purinergic signaling and dry eye.

Conflicts of Interest: Jesús Pintor, Fernando Huete-Toral, and Gonzalo Carracedo have a patent for the preparation and use of an extract of Artemia salina to treat the ocular surface (WO/2018/015582). The remaining authors have no financial or proprietary interest in any material or method mentioned.

\section{References}

1. Craig, J.P.; Nichols, K.K.; Akpek, E.K.; Caffery, B.; Dua, H.S.; Joo, C.K.; Liu, Z.; Nelson, J.D.; Nichols, J.J.; Tsubota, K.; et al. TFOS DEWS II Definition and Classification Report. Ocul. Surf. 2017, 15, 276-283. [CrossRef] [PubMed]

2. Stapleton, F.; Alves, M.; Bunya, V.Y.; Jalbert, I.; Lekhanont, K.; Malet, F.; Na, K.S.; Schaumberg, D.; Uchino, M.; Vehof, J.; et al. TFOS DEWS II Epidemiology Report. Ocul. Surf. 2017, 15, 334-365. [CrossRef] [PubMed]

3. Jones, L.; Downie, L.E.; Korb, D.; Benitez-Del-Castillo, J.M.; Dana, R.; Deng, S.X.; Dong, P.N.; Geerling, G.; Hida, R.Y.; Liu, Y.; et al TFOS DEWS II Management and Therapy Report. Ocul. Surf. 2017, 15, 575-628. [CrossRef]

4. Carracedo, G.; Crooke, A.; Guzman-Aranguez, A.; Perez de Lara, M.J.; Martin-Gil, A.; Pintor, J. The role of dinucleoside polyphosphates on the ocular surface and other eye structures. Prog. Retin. Eye Res. 2016, 55, 182-205. [CrossRef] [PubMed]

5. Habermacher, C.; Dunning, K.; Chataigneau, T.; Grutter, T. Molecular structure and function of P2X receptors. Neuropharmacology 2016, 104, 18-30. [CrossRef]

6. Von Kugelgen, I.; Harden, T.K. Molecular pharmacology, physiology, and structure of the P2Y receptors. Adv. Pharmacol. 2011, 61, 373-415. [CrossRef]

7. Guzman-Aranguez, A.; Santano, C.; Martin-Gil, A.; Fonseca, B.; Pintor, J. Nucleotides in the eye: Focus on functional aspects and therapeutic perspectives. J. Pharmacol. Exp. Ther. 2013, 345, 331-341. [CrossRef] [PubMed]

8. Huete, F.; Guzman-Aranguez, A.; Ortin, J.; Hoyle, C.H.; Pintor, J. Effects of diadenosine tetraphosphate on FGF9-induced chloride flux changes in achondroplastic chondrocytes. Purinergic Signal. 2011, 7, 243-249. [CrossRef] [PubMed]

9. Martin-Gil, A.; de Lara, M.J.; Crooke, A.; Santano, C.; Peral, A.; Pintor, J. Silencing of P2Y(2) receptors reduces intraocular pressure in New Zealand rabbits. Br. J. Pharmacol. 2012, 165, 1163-1172. [CrossRef] [PubMed]

10. Pintor, J.; Sanchez-Nogueiro, J.; Irazu, M.; Mediero, A.; Pelaez, T.; Peral, A. Immunolocalisation of P2Y receptors in the rat eye. Purinergic Signal. 2004, 1, 83-90. [CrossRef]

11. Pintor, J.; Peral, A.; Hoyle, C.H.; Redick, C.; Douglass, J.; Sims, I.; Yerxa, B. Effects of diadenosine polyphosphates on tear secretion in New Zealand white rabbits. J. Pharmacol. Exp. Ther. 2002, 300, 291-297. [CrossRef]

12. Yerxa, B.R.; Douglass, J.G.; Elena, P.P.; Caillaud, T.; Amar, T.; Edick, C.; Peterson, W.M. Potency and duration of action of synthetic P2Y2 receptor agonists on Schirmer scores in rabbits. Adv. Exp. Med. Biol. 2002, 506, 261-265. [CrossRef] [PubMed]

13. Dominguez-Godinez, C.O.; Martin-Gil, A.; Carracedo, G.; Guzman-Aranguez, A.; González-Méijome, J.M.; Pintor, J. In vitro and in vivo delivery of the secretagogue diadenosine tetraphosphate from conventional and silicone hydrogel soft contact lenses. $J$. Optom. 2013, 6, 205-211. [CrossRef]

14. Dominguez-Godinez, C.; Carracedo, G.; Pintor, J. Diquafosol Delivery from Silicone Hydrogel Contact Lenses: Improved Effect on Tear Secretion. J. Ocul. Pharmacol. Ther. 2018, 34, 170-176. [CrossRef]

15. Fujihara, T.; Murakami, T.; Nagano, T.; Nakamura, M.; Nakata, K. INS365 suppresses loss of corneal epithelial integrity by secretion of mucin-like glycoprotein in a rabbit short-term dry eye model. J. Ocul. Pharmacol. Ther. 2002, 18, 363-370. [CrossRef] [PubMed]

16. Endo, K.I.; Sakamoto, A.; Fujisawa, K. Diquafosol tetrasodium elicits total cholesterol release from rabbit meibomian gland cells via P2Y(2) purinergic receptor signalling. Sci. Rep. 2021, 11, 6989. [CrossRef]

17. Pintor, J.; Bautista, A.; Carracedo, G.; Peral, A. UTP and diadenosine tetraphosphate accelerate wound healing in the rabbit cornea. Ophthalmic Physiol. Opt. 2004, 24, 186-193. [CrossRef]

18. Mediero, A.; Peral, A.; Pintor, J. Dual roles of diadenosine polyphosphates in corneal epithelial cell migration. Investig. Ophthalmol. Vis. Sci. 2006, 47, 4500-4506. [CrossRef] [PubMed]

19. Loma, P.; Guzman-Aranguez, A.; Perez de Lara, M.J.; Pintor, J. Diadenosine tetraphosphate induces tight junction disassembly thus increasing corneal epithelial permeability. Br. J. Pharmacol. 2015, 172, 1045-1058. [CrossRef]

20. Loma, P.; Guzman-Aranguez, A.; Perez de Lara, M.J.; Pintor, J. Diadenosine tetraphosphate improves adrenergic antiglaucomatous drug delivery and efficiency. Exp. Eye Res. 2015, 134, 141-147. [CrossRef] [PubMed] 
21. Peral, A.; Loma, P.; Yerxa, B.; Pintor, J. Topical application of nucleotides increase lysozyme levels in tears. Clin. Ophthalmol. 2008, 2, 261-267.

22. Loma, P.; Guzman-Aranguez, A.; Perez de Lara, M.J.; Pintor, J. Lactoferrin Levels in Tears are Increased by the Topical Application of Diadenosine Tetraphosphate. Curr. Eye Res. 2016, 41, 1150-1152. [CrossRef]

23. Zhao, X.; Xia, S.; Chen, Y. Comparison of the efficacy between topical diquafosol and artificial tears in the treatment of dry eye following cataract surgery: A meta-analysis of randomized controlled trials. Med. Baltim. 2017, 96, e8174. [CrossRef] [PubMed]

24. Nam, K.; Kim, H.J.; Yoo, A. Efficacy and Safety of Topical 3\% Diquafosol Ophthalmic Solution for the Treatment of Multifactorial Dry Eye Disease: Meta-Analysis of Randomized Clinical Trials. Ophthalmic Res. 2019, 61, 188-198. [CrossRef] [PubMed]

25. Bremond-Gignac, D.; Gicquel, J.J.; Chiambaretta, F. Pharmacokinetic evaluation of diquafosol tetrasodium for the treatment of Sjogren's syndrome. Expert Opin. Drug Metab. Toxicol. 2014, 10, 905-913. [CrossRef] [PubMed]

26. Koh, S.; Ikeda, C.; Takai, Y.; Watanabe, H.; Maeda, N.; Nishida, K. Long-term results of treatment with diquafosol ophthalmic solution for aqueous-deficient dry eye. Jpn. J. Ophthalmol. 2013, 57, 440-446. [CrossRef] [PubMed]

27. Yamaguchi, M.; Nishijima, T.; Shimazaki, J.; Takamura, E.; Yokoi, N.; Watanabe, H.; Ohashi, Y. Real-world assessment of diquafosol in dry eye patients with risk factors such as contact lens, meibomian gland dysfunction, and conjunctivochalasis: Subgroup analysis from a prospective observational study. Clin. Ophthalmol. 2015, 9, 2251-2256. [CrossRef]

28. Nagahara, Y.; Koh, S.; Nishida, K.; Watanabe, H. Prolonged increase in tear meniscus height by 3\% diquafosol ophthalmic solution in eyes with contact lenses. Clin. Ophthalmol. 2015, 9, 1029-1031. [CrossRef] [PubMed]

29. Nam, K.T.; Ahn, S.M.; Eom, Y.; Kim, H.M.; Song, J.S. Immediate Effects of 3\% Diquafosol and 0.1\% Hyaluronic Acid Ophthalmic Solution on Tear Break-Up Time in Normal Human Eyes. J. Ocul. Pharmacol. Ther. 2015, 31, 631-635. [CrossRef]

30. Carpena-Torres, C.; Pintor, J.; Huete-Toral, F.; Rodriguez-Pomar, C.; Martínez-Águila, A.; Carracedo, G. Preclinical Development of Artificial Tears Based on an Extract of Artemia Salina Containing Dinucleotides in Rabbits. Curr. Eye Res. 2021, 46, 174-178. [CrossRef] [PubMed]

31. Finamore, F.J.; Warner, A.H. The occurrence of P1, P4-diguanosine 5'-tetraphosphate in brine shrimp eggs. J. Biol. Chem. 1963, 238, 344-348. [CrossRef]

32. Gilmour, S.J.; Warner, A.H. The presence of guanosine $5^{\prime}$-diphospho- $5^{\prime}$-guanosine and guanosine $5^{\prime}$-triphospho- $5^{\prime}$-adenosine in brine shrimp embryos. J. Biol. Chem. 1978, 253, 4960-4965. [CrossRef]

33. Carpena-Torres, C.; Pintor, J.; Pérez de Lara, M.J.; Huete-Toral, F.; Crooke, A.; Pastrana, C.; Carracedo, G. Optimization of a Rabbit Dry Eye Model Induced by Topical Instillation of Benzalkonium Chloride. J. Ophthalmol. 2020, 2020, 7204951. [CrossRef] [PubMed]

34. Fujihara, T.; Murakami, T.; Fujita, H.; Nakamura, M.; Nakata, K. Improvement of corneal barrier function by the P2Y(2) agonist INS365 in a rat dry eye model. Investig. Ophthalmol. Vis. Sci. 2001, 42, 96-100.

35. Ikeda, K.; Simsek, C.; Kojima, T.; Higa, K.; Kawashima, M.; Dogru, M.; Shimizu, T.; Tsubota, K.; Shimazaki, J. The effects of 3\% diquafosol sodium eye drop application on meibomian gland and ocular surface alterations in the $\mathrm{Cu}$, Zn-superoxide dismutase-1 (Sod1) knockout mice. Graefes. Arch. Clin. Exp. Ophthalmol. 2018, 256, 739-750. [CrossRef] [PubMed]

36. Willcox, M.D.P.; Argueso, P.; Georgiev, G.A.; Holopainen, J.M.; Laurie, G.W.; Millar, T.J.; Papas, E.B.; Rolland, J.P.; Schmidt, T.A.; Stahl, U.; et al. TFOS DEWS II Tear Film Report. Ocul. Surf. 2017, 15, 366-403. [CrossRef]

37. Hori, Y.; Kageyama, T.; Sakamoto, A.; Shiba, T.; Nakamura, M.; Maeno, T. Comparison of Short-Term Effects of Diquafosol and Rebamipide on Mucin 5AC Level on the Rabbit Ocular Surface. J. Ocul. Pharmacol. Ther. 2017, 33, 493-497. [CrossRef] [PubMed]

38. Li, X.; Kang, B.; Eom, Y.; Lee, H.K.; Kim, H.M.; Song, J.S. The Protective Effect of a Topical Mucin Secretagogue on Ocular Surface Damage Induced by Airborne Carbon Black Exposure. Investig. Ophthalmol. Vis. Sci. 2019, 60, 255-264. [CrossRef]

39. Shigeyasu, C.; Hirano, S.; Akune, Y.; Yamada, M. Diquafosol Tetrasodium Increases the Concentration of Mucin-like Substances in Tears of Healthy Human Subjects. Curr. Eye Res. 2015, 40, 878-883. [CrossRef]

40. Shigeyasu, C.; Yamada, M.; Akune, Y.; Tsubota, K. Diquafosol sodium ophthalmic solution for the treatment of dry eye: Clinical evaluation and biochemical analysis of tear composition. Jpn. J. Ophthalmol. 2015, 59, 415-420. [CrossRef] [PubMed]

41. Crooke, A.; Mediero, A.; Guzman-Aranguez, A.; Pintor, J. Silencing of P2Y2 receptor delays Ap4A-corneal re-epithelialization process. Mol. Vis. 2009, 15, 1169-1178. [PubMed]

42. Mediero, A.; Guzman-Aranguez, A.; Crooke, A.; Peral, A.; Pintor, J. Corneal re-epithelialization stimulated by diadenosine polyphosphates recruits RhoA/ROCK and ERK1/2 pathways. Investig. Ophthalmol. Vis. Sci. 2008, 49, 4982-4992. [CrossRef] [PubMed]

43. Mediero, A.; Crooke, A.; Guzman-Aranguez, A.; Pintor, J. Phospholipase C/Protein Kinase C pathway is essential for corneal re-epithelialization induced by Ap(4)A. Curr. Eye Res. 2011, 36, 1108-1115. [CrossRef] [PubMed]

44. Klepeis, V.E.; Weinger, I.; Kaczmarek, E.; Trinkaus-Randall, V. P2Y receptors play a critical role in epithelial cell communication and migration. J. Cell Biochem. 2004, 93, 1115-1133. [CrossRef] [PubMed]

45. Weinger, I.; Klepeis, V.E.; Trinkaus-Randall, V. Tri-nucleotide receptors play a critical role in epithelial cell wound repair. Purinergic Signal. 2005, 1, 281-292. [CrossRef]

46. Kim, Y.H.; Yang, I.J.; Nguyen, L.T.H.; Gum, S.I.; Yu, S.; Lee, G.J.; Kim, B.A.; Jung, J.C.; Park, Y.J. Effect of Diquafosol on Hyperosmotic Stress-induced Tumor Necrosis Factor- $\alpha$ and Interleukin-6 Expression in Human Corneal Epithelial Cells. Korean J. Ophthalmol. 2020, 34, 1-10. [CrossRef] [PubMed] 
47. Moon, I.; Kang, H.G.; Yeo, A.; Noh, H.; Kim, H.C.; Song, J.S.; Ji, Y.W.; Lee, H.K. Comparison of Ocular Surface Mucin Expression After Topical Ophthalmic Drug Administration in Dry Eye-Induced Mouse Model. J. Ocul. Pharmacol. Ther. 2018, 34, 612-620. [CrossRef] [PubMed]

48. Park, J.H.; Moon, S.H.; Kang, D.H.; Um, H.J.; Kang, S.S.; Kim, J.Y.; Tchah, H. Diquafosol Sodium Inhibits Apoptosis and Inflammation of Corneal Epithelial Cells via Activation of Erk1/2 and RSK: In Vitro and In Vivo Dry Eye Model. Investig. Ophthalmol. Vis. Sci. 2018, 59, 5108-5115. [CrossRef] [PubMed]

49. Jamerson, E.C.; Elhusseiny, A.M.; ElSheikh, R.H.; Eleiwa, T.K.; El Sayed, Y.M. Role of Matrix Metalloproteinase 9 in Ocular Surface Disorders. Eye Contact Lens 2020, 46 (Suppl. 2), S57-S63. [CrossRef] [PubMed]

50. Idzko, M.; Ferrari, D.; Eltzschig, H.K. Nucleotide signalling during inflammation. Nature 2014, 509, 310-317. [CrossRef]

51. Li, C.; Song, Y.; Luan, S.; Wan, P.; Li, N.; Tang, J.; Han, Y.; Xiong, C.; Wang, Z. Research on the stability of a rabbit dry eye model induced by topical application of the preservative benzalkonium chloride. PLoS ONE 2012, 7, e33688. [CrossRef]

52. Ehrenberg, M.; Zolotariov, E.; Loeb, E.; Poliansky, V.; Levy, A. Combining Sodium Hyaluronate and Polyvinylpyrrolidone Therapies for the Rabbit Cornea: A New Approach to Relief of the Human Dry Eye Syndrome. Curr. Eye Res. 2015, 40, 913-922. [CrossRef] [PubMed]

53. Singh, R.S.; Kaur, N.; Sharma, R.; Rana, V. Investigating the potential of carboxymethyl pullulan for protecting the rabbit eye from systematically induced precorneal tear film damage. Exp. Eye Res. 2019, 184, 91-100. [CrossRef] [PubMed]

54. Faria, N.V.L.; Sampaio, M.O.B.; Viapiana, G.N.; Seabra, N.M.; Russ, H.H.; Montiani-Ferreira, F.; Mello, P.A.A. Effects of benzalkonium chloride and cyclosporine applied topically to rabbit conjunctiva: A histomorphometric study. Arq. Bras. Oftalmol. 2019, 82, 310-316. [CrossRef] [PubMed]

55. Li, Y.J.; Luo, L.J.; Harroun, S.G.; Wei, S.C.; Unnikrishnan, B.; Chang, H.T.; Huang, Y.F.; Lai, J.Y.; Huang, C.C. Synergistically dual-functional nano eye-drops for simultaneous anti-inflammatory and anti-oxidative treatment of dry eye disease. Nanoscale 2019, 11, 5580-5594. [CrossRef] [PubMed]

56. Choi, J.H.; Li, Y.; Jin, R.; Shrestha, T.; Choi, J.S.; Lee, W.J.; Moon, M.J.; Ju, H.T.; Choi, W.; Yoon, K.C. The Efficiency of Cyclosporine A-Eluting Contact Lenses for the Treatment of Dry Eye. Curr. Eye Res. 2019, 44, 486-496. [CrossRef] [PubMed]

57. Tseng, C.L.; Hung, Y.J.; Chen, Z.Y.; Fang, H.W.; Chen, K.H. Synergistic Effect of Artificial Tears Containing Epigallocatechin Gallate and Hyaluronic Acid for the Treatment of Rabbits with Dry Eye Syndrome. PLoS ONE 2016, 11, e0157982. [CrossRef]

58. Luo, L.J.; Lai, J.Y. Epigallocatechin Gallate-Loaded Gelatin-g-Poly(N-Isopropylacrylamide) as a New Ophthalmic Pharmaceutical Formulation for Topical Use in the Treatment of Dry Eye Syndrome. Sci. Rep. 2017, 7, 9380. [CrossRef]

59. Tseng, C.L.; Chen, Z.Y.; Renn, T.Y.; Hsiao, S.H.; Burnouf, T. Solvent/Detergent Virally Inactivated Serum Eye Drops Restore Healthy Ocular Epithelium in a Rabbit Model of Dry-Eye Syndrome. PLoS ONE 2016, 11, e0153573. [CrossRef]

60. Huang, H.Y.; Wang, M.C.; Chen, Z.Y.; Chiu, W.Y.; Chen, K.H.; Lin, I.C.; Yang, W.V.; Wu, C.C.; Tseng, C.L. Gelatin-epigallocatechin gallate nanoparticles with hyaluronic acid decoration as eye drops can treat rabbit dry-eye syndrome effectively via inflammatory relief. Int. J. Nanomed. 2018, 13, 7251-7273. [CrossRef]

61. Lin, T.; Lu, Y.; Zhang, X.; Gong, L.; Wei, C. Treatment of dry eye by intracanalicular injection of a thermosensitive chitosan-based hydrogel: Evaluation of biosafety and availability. Biomater. Sci. 2018, 6, 3160-3169. [CrossRef] [PubMed]

62. Efron, N. Grading scales for contact lens complications. In Contact Lens Complications, 3rd ed.; Elsevier: Amsterdam, The Netherlands, 2012; pp. 301-305.

63. Peral, A.; Pintor, J. Ocular mucin visualization by confocal laser scanning microscopy. Cornea 2008, 27, 395-401. [CrossRef] [PubMed] 